\title{
Neuroscience, Linguistics and Psycholinguistics Advances Applied to Early Literacy Teaching ${ }^{\prime}$
}

\author{
Leonor Scliar-Cabral
}

Correspondence: Leonor Scliar-Cabral, Rua São Miguel, 1106, Bairro João Paulo, CEP 88030-320 Florianópolis, SC Brasil. ORCID: http://orcid.org/0000-0003-3163-5482

Received: June 8, 2020

doi:10.5430/elr.v9n3p15
Accepted: July 30, 2020

URL: https://doi.org/10.5430/elr.v9n3p15

\begin{abstract}
I discuss the lack of linguistic and psycholinguistic fundamentals compromising the teaching-learning models of early literacy, as well as the ignorance of reading neuroscience most recent contributions, arguing with linguistic and neuroscience theories about perceptual invariant units, like phonemes and graphemes. I also explain the difference between phoneme and sound and between grapheme and letter as well as the existence of hierarchical linguistic levels. All those fundamentals pave the Scliar Early Literacy System (SSA), applied on an experiment run at Lagarto, Sergipe State, on the Brazilian Northeastern, that showed the lowest scores in the 2016 National Literacy Assessment (ANA). METHOD: José Humberto dos Santos Santana, distance SSA Course student, belonging to Lagarto municipal staff, organized the five researchers group to implement the SSA in two Lagarto schools. Teachers Patrícia Vieira Barbosa Faria and Jaqueline da Silva Nascimento were 75 children teaching pioneers, in February, 2017, using SSA, Module 1 , method and materials, focusing on reading learning at the municipal schools Raimunda Reis, RR (two classes) and Manoel de Paula Menezes Lima, MPML (one class). On 2018, the same teachers followed the same children in the $2^{\text {nd }}$ grade, applying SSA, Module 2, method and materials, focusing on writing learning. Educators received continuous distance training, first, fortnightly and, starting in 2018, twice every week: Tuesdays, for educators who worked with $2^{\text {nd }}$ grade children and, on Wednesdays, for $1^{\text {st }}$ grade educators, from Elementary School. Distant classes last one hour and a half each. RESULTS: The 2018 More Early Literacy Program assessment describes the lowest level 1, as the one where children barely identify one word or the other. In this level two Lagarto schools dropped to 8.7 (RR) and 9.1\% (MPML), while at the highest level, dealing with children who have a desirable reading performance, they reached the percentages of $\mathbf{3 4 . 8}$ (RR) and 31.8 (MPML). Compare such results with the 2016 National Literacy Assessment (ANA) performance in the State of Sergipe: level 1, 45.28; highest level, 3.02. In 2018, Lagarto Municipal Education Secretariat expanded its adhesion to SSA, reaching an average of 490 children from the $1^{\text {st }}$ (18 classes) and $2^{\text {nd }}$ (3 classes) grades of Elementary School, taking into account reading and writing, respectively. The Secretariat guaranteed the continuous training of 18 teachers who attend the $1^{\text {st }}$ year and the 5 who attend the $2^{\text {nd }}$ year for applying the SSA. In 2019, given the proposal success, more than 1000 children benefited from the project.
\end{abstract}

Keywords: Scliar Early Literacy System (SSA), reading neuroscience, phoneme and sound, grapheme and letter, hierarchical linguistic levels

\section{Introduction}

Even in highly developed countries, such as the USA, functional illiteracy rates remain very high: Among "more than 19,000 adults (ages 16 and older) in households or prisons" (IES 2006: iii), "14 percent had Below Basic health literacy" (ib.: v).

As educators, concerned with ensuring greater people inclusion in the informational society, allowing them exercising their citizenship, the use of cultural assets and the access to qualified work, it is imperative to highlight this disastrous scenario causes.

Among the numerous causes, I will discuss in this paper the lack of linguistic and psycholinguistic fundamentals compromising the teaching-learning models of early literacy, as well as the ignorance of reading neuroscience most recent contributions.

${ }^{1}$ Programa de Pós-Graduação em Linguística - Universidade Federal de Santa Catarina, Florianópolis, Brasil. 
I refer specifically to perceptual invariant units concepts, such as phonemes and graphemes, to the difference between phoneme and sound and between grapheme and letter and to the existence of hierarchical linguistic levels. They show a counterpart in the brain architecture. Consequently, there was an introduction, in alphabetical writing systems, of two more levels, the one respecting the invariant features making up letters and the other respecting letters themselves, since the last ones perform graphemes.

In addition, I report the Scliar Early Literacy System (SSA) development that innovated in Brazil the early literacy teaching and learning. SSA applied neuroscience to the automation of invariant letter features and letters recognition; linguistics to the automation of written unstressed words (clitics) recognition and word stress attributing while reading Brazilian Portuguese texts. SSA also applied psycholinguistics to explain the processing differences between learning how to read and how to write.

I then describe an experiment developed in one Brazilian Northeastern State (Sergipe), chosen because it presented the worst reading and writing results (together with Alagoas State), at the end of the early literacy cycle ( $3^{\text {rd }}$ Elementary School grade), according to the 2016 National Literacy Assessment (ANA) (INEP, 2017). The project started in 2017 and I will present and discuss the results.

\subsection{Early Literacy Models Lacking Neuroscience, Linguistic and Psycholinguistic Fundamentals}

I present one example of early literacy teaching-learning nâ̂ve model totally lacking neuroscience, linguistic and psycholinguistic fundamentals. Although supported by the prestigious University of Oregon, The Center of Teaching and Learning (CTL) asserts:

The alphabetic principle is composed of two parts:

Alphabetic Understanding: Words are composed of letters that represent sounds.

Phonological Recoding: Using systematic relationships between letters and phonemes (letter-sound correspondence)

This alphabetical principle definition, for lacking neuroscientific, linguistic and psycholinguistic fundamentals, presents flaws, which will be clarified bellow.

\subsubsection{The Difference Between Sound and Phoneme}

Linguists, faced at the countless variants produced by the same word speech sounds, registered on oscillograms, had to solve the following problem: How do people understand each other?

The explanation came out from the first theories that proposed the phoneme as different from the sound, starting with Baudouin De Courtenay $(1845$ - 1929): he described the phoneme as the speech sounds fusion of the impressions given by the pronunciations resulting in one psychological equivalent in the mind.

The speaker's goal is producing a sound, but the phonetic context determines the actual articulated sound (De Courtenay, 1972). Kruszewsky (1995), a disciple of De Courtenay, with whom he worked, developed the alternations theory. For the first time, he systematically presents what we now know as phoneme allophonic variants, conditioned by the context.

Trubetskoy (1970), the Prague Linguistics Circle mentor, defines the phoneme as the smallest distinctive unit within a given language structure, while Jakobson (1971) defines it as a bundle of distinctive features. In his work, Principles of phonology, Trubetskoy (1970), establishes phonology as a separate discipline from phonetics.

Saussure (1972: 164) states: "Phonemes are, above all, opposing, relative and negative entities".

From all above definitions, we may infer:

(a) - The represented psychological nature of the phoneme different physical performances.

(b) - The represented invariance, which covers any of each phoneme performances, as long as they do not surpass the borders that delimit one phoneme as distinct from another.

(c) - The meaning distinctive function of such representations, although they are meaning devoid, guaranteed by the fact that they paradigmatically oppose each other, within the same linguistic structure.

Such postulates became explicit through Glossematics theory (Hjelmslev, 1953), when it opposes substance to form. Hjelmslev applies such opposition to all linguistic levels: phonological, morphological, lexical, syntactic and semantic. This dichotomy already appeared in Saussure's speech circuit theory (1972: 27): acoustic waves (physical nature substance) are the study object of acoustic physics or phonetics and articulated gestures (physiological nature substance), are the study object of physiology, or articulatory phonetics, while the signifier (Saussure's significant, a psychic nature entity, belonging to langue), is the object of linguistics itself. 
Consequently, letters do not represent sounds (I will examine the first mistake, in the next section). Instead, graphemes represent phonemes. For instance, in American English, there are two allophones (sounds) context dependent of phoneme /a/: if in a stressed closed syllable, it is followed by a voiced consonant, like in "cab", it is pronounced as long [a:]; if in a stressed closed syllable, it is followed by a voiceless consonant, like in "kat", it is pronounced as short [a]. Although there are two different sounds, there are not 'two different letters' to represent each one sound. What we have is one grapheme $<a>$, which represents phoneme $/ a /$, and letter ' $a$ ' performs grapheme $<a>$. The alphabetic principle asserts that letters are different from graphemes, which I will examine in the next section.

\subsection{The Difference Between Letter and Grapheme}

Human species, characterized by a bio-psychological apparatus, allows constructing material and spiritual culture and by neurons plasticity able for learning new features. Under the pressure of various socio-economic needs, men invented new tools and techniques, which did not cause genetic changes but epigenetic ones, hence the first imply a longer time if compared with the last, caused by new techniques.

This happened with writing systems: the proto-cuneiform (Michailowski, 1996: 33) and the Egyptian script tradition, which included the hieroglyphs (Ritner, 1996: 73) known as the oldest writing systems in the world, were invented at the end of the fourth millennium B.C.E. Even the writing systems evolution demonstrates that what took place was not a genetic change on the genes, which process natural languages, but a growing adaptation of the neural circuits on the occipital-temporal ventral region of the brain for the recognition of written words (Dehaene, 2007: 147).

If we compare the period when natural languages emerged with that when the first writing systems are attested, there is an enormous chronological distance. It raises important conclusions for understanding the reading processes and the learning process involved. They are even more crucial in the case of the alphabetic systems, derived from the protoSinaitic script, whose earliest manifestation around 1,400 B.C.E. appears on a small sandstone sphinx dedicated to the goddess Hathor (recent research reveals older examples existence of a similar script, discovered in central Egypt and dating from around 1,800 B.C.E. (Scliar-Cabral, 2009: 147).

The most important conclusion is that the writing systems are not spontaneously and compulsorily acquired, but they occur in a systematic learning context, namely at school. All evidences demonstrate, on the other hand, that such learning is not easy. I will stress those difficulties examining them on the alphabetic system.

Both oral and alphabetic systems share some common architectonic properties, namely, three articulations, the first, combining meaningful units, the second, combining meaningless units, respectively phonemes and graphemes, and the third, articulating phonetic features and letters features. In contrast, however, to the traits that make up the phoneme, the letters features do not have the function of distinguishing meanings but the function of contrasting letters to each other.

As the alphabetical systems are secondary to the oral ones, they use scripts composed of letters, shared by several writing languages, as is the case of the Latin alphabet.

Thus, while graphemes and their values are specific to each language, the letters and their recognition are independent of the language. While the recognition of each letter does not depend on its position in the word, many graphemes value will depend on the position they occupy in it. For example, in 'complicity', in English, we recognize the first and seventh letters as the same, but the graphemes they perform are not the same. The first grapheme $\langle\mathbf{c}>$ represents the phoneme $/ \mathrm{k} /$ and the seventh represents the phoneme $/ \mathrm{s} /$. In the word 'cumplicidade' (Port.), the first and seventh letters are the same as in English, however, while in English there are two graphemes $\langle 0\rangle,\langle\mathrm{m}\rangle$, in Portuguese the grapheme $<u m>$, represents the posterior high nasal vowel. Differently from English, nasal consonants cannot occupy syllable final position.

Therefore, the invariant features that distinguish one letter from another are the same in Portuguese, English, French, Italian or any other written language that adopts the Latin script type. The processing is the same and children, who are learning to read and write in any of the languages that adopt Latin script, will face the same difficulties to recognize the features and to automate such recognition, which is not the case with graphemes.

I emphasize that letters do not distinguish meaning: they do not represent phonemes. What distinguishes written meaning is the grapheme. Thus, in the word 'mass', we have four letters, but three graphemes, $\langle\mathbf{m}\rangle,\langle\mathbf{a}\rangle,\langle\mathbf{s s}\rangle$. The difference in meaning between 'mass' and many written words that make a minimal pair with it is obtained by replacing

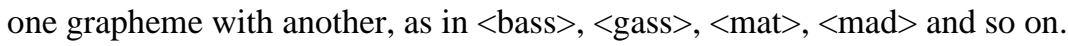




\section{Hierarchical Linguistic Levels}

Based on reading neuroscience, I will demonstrate the verbal language processing levels hierarchical nature. In order to recognize the processed entities, pairing with invariant units occurs encompassing any each class achievements, as long as they do not exceed the boundaries delimiting it as distinct class from another. The lower the level, the smaller the paradigm elements number, the more closed to new ones inclusion, the more conditioned to the higher level, the more necessary its automation, therefore, less conscious and requiring less processing time. I will exemplify with the reading processing.

The first steps preceding reading itself begin, when the most sensitive retina part, the cones, or photon receptors attach themselves to a word, on the printed line. They cover an angle of no more than 1.5 degrees, approximately ten or twelve characters, including blanks: in writing systems with direction from left to right, three or four to the left of the center of the eye and seven or eight to the right. During the saccade movements, the cones do not capture anything (McConkie \& Keith Rayner, 1975).

Petersen and colleagues (1988) discussed the results obtained with the positron emission tomography technique, through which they revealed the hierarchy of regions involved in word recognition (written or spoken) and its articulation and internal meaning manipulation.

The optic nerve conducts the stimuli harvested by photoreceptors in the retina. They explode in a mosaic of light patches on the occipital region primary cortex, which will process it (Dehaene, 2009: 130).

Take, for instance, face and written word recognition. Experiments results reveal two processing initial stages in the occipital cortex. During the first one, the two types of images are not distinguished. They activate the same primary occipital area on both hemispheres, Brodmann's area 17 (Carter \& Gray, 1918, plate 727), in the left and right hemispheres, just behind the head, where a first analysis extract elementary shapes: lines, curves and surfaces, not recognizing whether they are faces or letters (Dehaene, 2009: 78).

Then, after a screening, the second phase occurs with sending the invariant features related to the face to the right occipital cortex secondary area, while those related to letters converge to the area specialized on recognizing the written word, that is, the left ventral temporalis occipital region, already proven by neuroscience research (Dehaene, 2009: 78), if the individual became literate.

At each level, the resulting units are of a more complex and abstract nature. Neurons in the left ventral occipitaltemporal region recognize the invariant features that make up the letters, regardless of their size, case (UPPERCASE or lowercase), font and style (print, handwritten, italic, bold or underlined, etc.), or the position they occupy in the word (Dehaene, 2009: 20).

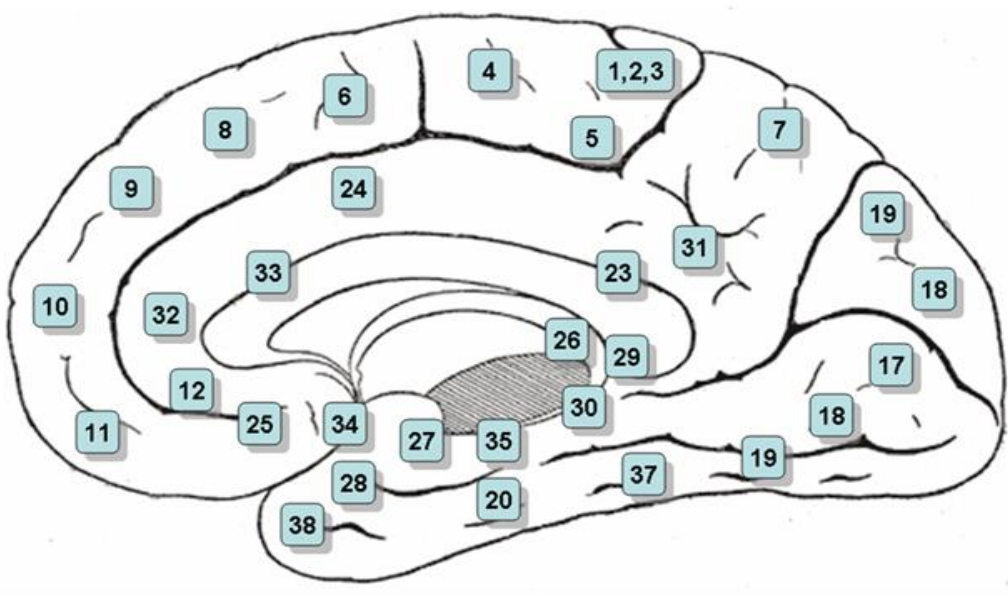

Figure 1. Medial view of the brain, with Brodmann's areas. Source: Carter \& Gray (1918, plate 727)

Invariance recognition is possible and necessary for two reasons, because firstly, the primate visual system must recognize the basic forms of what is found in nature, regardless of the variants, depending on the distance, the viewing angle, the incidence of light and shadow and the part in relation to the whole (Grainger, Rey \& Dufau, 2008; Spratting, 2005). Secondly, and this is specifically human, because invariance recognition explains the left ventral occipital- 
temporal region neurons ability to recognize the invariant features that make up the letters. The respective axons (neurons extensions, which carry information to other neurons through the synapse mechanism) connect all regions that process verbal language and simultaneously to the meaning processing area.

At each level, the previous units structure themselves in an increasing order of complexity and elements number. The first level is that of the features articulated simultaneously and not in a chain, to form each letter, whose function is performing a grapheme. The second level is that of graphemes: associated with phonemes they represent, both function to distinguish the basic meanings of referential or grammatical units. One or two letters perform a grapheme in Portuguese writing system.

The third level is that of morphemes, the minimal meaning units either purely grammatical or referential. The fourth level is that of the word, which functions as the minimal syntactic unit. The fifth is the level of nominal, verbal or prepositional phrases. The sixth level is that of clauses, whose function is propositional. The seventh level is that of sentences, whose function is coordinating and / or subordinating clauses and the eighth or last level is textual, whose function is articulating ideas, in a coherent way, around a thematic unit (macrostructure).

Alphabetic systems are secondary in relation to the oral ones and obey the hierarchical architecture of their structure in levels. The letter features recognition level is the processing lowest one.

\section{Latin Script Printed Invariant Features}

We will see, next, what are the invariant features that distinguish one letter from others, in the Latin printed system.

Nine primary features: $\mid \mathbf{O}-\mathbf{1} \mathbf{c} \mathbf{U} \supset \sim$.

Other additional features:

- straight line position: vertical, horizontal or inclined. For instance, the letter $\mathbf{E}$ shows a vertical straight line and three horizontal ones, while letter $\mathbf{V}$ shows two inclined straight lines;

- straight line size: it can be noticed that the horizontal straight lines are always shorter than vertical ones (both preserving each size in the same font). Compare, for instance, those sizes in the following letters: E, F, H, L and T.

- relations among features in the same letter: relations may be among straight lines (in different positions), among curves or mixed, varying the place where the smaller straight lines are placed in relation to the main axis and how many they are. Therefore, the sole difference between $\mathbf{E}$ and $\mathbf{F}$ consists in the fact that $\mathbf{E}$ has one more straight line at the bottom and both are different from $\mathbf{L}$ because the last letter has only one horizontal straight line at the bottom. In the case of the letter $\mathbf{T}$, the vertical straight line touches at the top just the middle of the horizontal straight line, while in the case of $\mathbf{H}$, the two parallel vertical straight lines are linked at their middle by an horizontal one. Those five capital letters articulate two features, their sole difference being the way they relate and how many times they repeat: L T F E H.

An example of relation between curves is letter $\mathbf{S}$ (both capital and lower case ones), where the curve $\mathbf{c}$ mirrors top down and right to left. Besides this difficulty, the grapheme presents additional ones since it may represent different phonemic values.

The most common are mixed relations. A small curve articulated with a straight vertical line, at the bottom or top, at right or left side, combined with a semicircle, repeated or cut by a very small horizontal straight line makes the differences among the following letters: $\mathbf{J}, \mathbf{a}, \mathbf{f}, \mathbf{g}, \mathbf{h}, \mathbf{j}, \mathbf{m}, \mathbf{n}, \mathbf{r}, \mathbf{t}$ and $\mathbf{u}$.

- direction towards right or left side, towards bottom or top (mirroring). This last feature is the most difficult one, since this difference perception is against the natural neurons disposition to find symmetry on the visual cues. This difference is the sole one between the following pairs: $\mathbf{b} / \mathbf{d}, \mathbf{p} / \mathbf{q}, \mathbf{M} / \mathbf{W}, \mathbf{n} / \mathbf{u}, \mathbf{b} / \mathbf{p}, \mathbf{d} / \mathbf{q}$ and, approximately, between $\mathbf{A} / \mathbf{V}, \mathbf{S} / \mathbf{Z}, \mathbf{a} / \mathbf{e}, \mathbf{s} / \mathbf{z}$ and $\mathbf{f} / \mathbf{j}$.

- Exceeding the imaginary baseline (lower case only): $\mathbf{g} \mathbf{j} \mathbf{~ p ~ q ~} \mathbf{y}$.

In order to save features, the same one sometimes appears identifying different letters, requiring information from the distributional context to remove ambiguity. An example is the vertical line $\mathbf{I}$, which, in isolation, can be either a capital letter that appears in the name Ivy, or the lower case that appears in the word love. It is necessary, therefore, the context, or the prior knowledge, to clarify which letter it is. We infer, therefore, that, in these cases, it is not enough recognizing the features for identifying the letter. In the next sections, I will present an experiment developed in Brazilian Northeastern, where I applied neuroscience, linguistics and psycholinguistics advances already discussed to early literacy teaching and learning. 


\section{Scliar Early Literacy System (SSA) at Lagarto, Sergipe State}

Public school students in Brazilian Northeastern had the lowest scores in the 2016 National Literacy Assessment, ANA (INEP, 2017), conducted by the Brazilian Education Ministry.

In the 2016 National Early Literacy Assessment (ANA) (INEP, 2017), 2,160,601 students from Brazilian public schools were evaluated at the end of the 3rd year of the Early Literacy Cycle, in reading and writing, among whom only $12.99 \%$ reached the aimed level (4) in reading and only $8.28 \%$ reached the aimed level (5) in writing. However, in the town of Lagarto (Sergipe State), which, according to the aforementioned evaluation, had ranked last in Brazil, with only $3.02 \%$ of students at the aimed level in reading, and penultimate place in writing, with only $1.84 \%$, things became quite different. Taught by the Scliar Early Literacy System, seventy children were Reading with fluency and comprehension and, above all, with pleasure, by the end of their first year, in 2017 (Scliar-Cabral, 2019: 271-2).

Due to these results, we turned our efforts to Sergipe and Alagoas. In 2017, we began the SSA implementation in Lagarto, SE and S. José da Laje, AL. In this paper, I will report the Lagarto experiment.

Lagarto is one of the largest cities in Sergipe State. It covers an area of $969,577 \mathrm{~km}^{2}$ and an estimated population of 101,305 inhabitants.

\subsection{Methodology}

Researchers Group and starting students: After attending, in 2016, the SSA Distance Extension Course that I delivered at the Federal University of Santa Catarina (UFSC), José Humberto dos Santos Santana, belonging to Lagarto municipal staff, organized the researchers group to implement the SSA in two Lagarto schools. He obtained all the Lagarto Education Municipal Secretariat support for instructing the team of teachers and educational advisors, including teachers Patrícia Vieira Barbosa Faria and Jaqueline da Silva Nascimento, who were 75 children teaching pioneers, in February, 2017, using SSA method and materials, at the municipal schools Raimunda Reis, RR (two classes) and Manoel de Paula Menezes Lima. MPML (one class).

From September 2017 onwards, I started to give distance training myself, first, fortnightly and, starting in 2018, twice every week: Tuesdays, for educators who worked with $2^{\text {nd }}$ grade children and, on Wednesdays, for $1^{\text {st }}$ grade educators, from elementary school. Distant classes last one hour and a half each.

Materials: It is necessary to support teachers with an adequate systematization of the latest neuroscience, linguistics and psycholinguistics advances adapted to the linguistic context and the Brazilian reality, encouraging them to apply new methodologies to achieve full literacy in Portuguese Language. I elaborated materials for two Modules, the first one directed to teaching-learning how to read and the second one to teaching-learning how to write. Bellow, $1^{\text {st }}$ Module books for educators:

The book with SSA fundamentals for teaching-learning how to read, which is Scliar-Cabral's (2013) Sistema Scliar de alfabetização - Fundamentos and the book containing the lesson plans and scripts for developing classroom activities with students in the $1^{\text {st }}$ year of Elementary School, which is Scliar-Cabral's (2018) Sistema Scliar de alfabetização. Roteiros para o professor.

$1^{\text {st }}$ Module books for children: An illustrated storybook booklet, which children love: Scliar-Cabral's (2014) Aventuras de Vivi (Vivi's adventures) and the book for early literacy exercises, Scliar-Cabral's (2020a) Sistema Scliar de alfabetização. Caderno de Atividades: Módulo 1, Leitura.

$2^{\text {nd }}$ Module books for educators: The book with SSA fundamentals for teaching-learning how to write, which is Scliar-Cabral's (2020b) Sistema Scliar de alfabetização - Fundamentos da escrita and the book containing the lesson plans and scripts for developing classroom activities with students in the $2^{\text {nd }}$ year of elementary school, which is ScliarCabral's (2020c) Sistema Scliar de alfabetização. Roteiros para o professor.

$2^{\text {nd }}$ Module books for children: An illustrated storybook booklet, Scliar-Cabral's (2020d) Aventuras de Vivi no mundo da escrita (Vivi's adventures in the writing world) and the book for early literacy exercises, Scliar-Cabral's (2020e) Sistema Scliar de alfabetização. Caderno de Atividades: Módulo 2, Escrita (including cursive letter modeling).

Children's activities for reading learning: It consists in firstly recognizing the direction of the features that differentiate letters from each other and, secondly, in mastering the grapheme values, associating them with the phonemes they represent.

It was possible to elaborate the grapheme decoding exercises into phonemes, in an increasing complexity order, thanks to the fact that I (Scliar-Cabral, 2003) had systematically described those Brazilian Portuguese writing system conversion rules. 

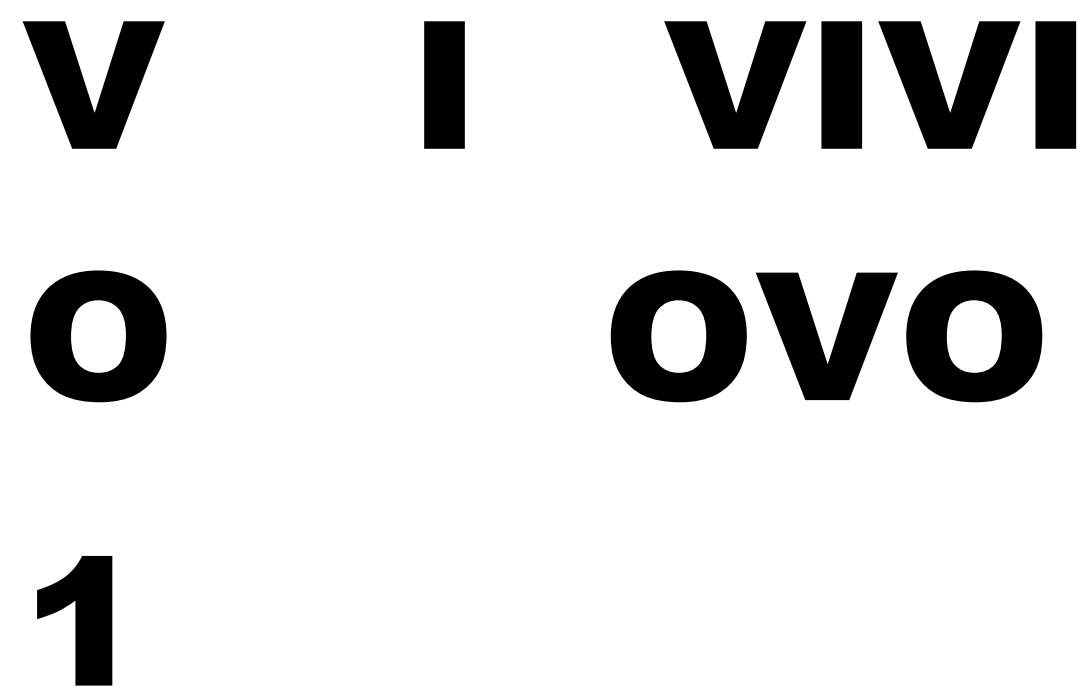

Figure 2. Book of activities first exercise: going through the letter features with the finger, producing the sound that performs the phoneme and clapping harder on the stressed syllable, reading the word aloud

The two practices must be performed simultaneously and the graphemes, taken from keywords: neurons recycling to deal with direction, position (topological aspects) and the number (mathematical aspects) of features that form letters is the necessary step for their recognition and for their passage to the grapheme level.

Because we process speech as a continuum, there are several phenomena arising that will make opaque the delimiting boundary where the word ends and where it begins, unlike what occurs in the written system, delimited by blanks as already explained. The most important consequence for reading is that in many cases the learner's phonological lexicon will not match what he/she will find in the textbooks. These architecture lower levels must be automated to release cognition for the highest and most creative levels processing.

Children's activities for writing learning: In the $2^{\text {nd }}$ Module, the SSA innovates activities by promoting textual production to: a) defining communicative intention; b) planning; c) linearizing; d) encoding e) executing and f) text monitoring. I highlight that, in the item "encoding", I apply the rules of phoneme into grapheme encoding in written Brazilian Portuguese (Scliar-Cabral, 2003).

In "defining the communicative intention", activities involve the appropriate and necessary genres for the seven-yearold children, such as, invitation, fictional and factual narrative, warning, note and agenda

In the planning item, children learn the scheme technique, which will ensure the textual coherence maintenance and paragraphing. In linearization, activities develop concept translation into lexical items, both those that refer to external experience, that is, the syntactic class noun, verb and adjective, and those that refer to purely grammatical meaning. Graphemic encoding activities precede motor gestures automating activities that command motor execution, whether handwritten or digital.

\section{Results}

Compare the 2016 National Literacy Assessment (ANA) results (INEP, 2017) in the State of Sergipe with the 2018 More Early Literacy Program assessment results (Ministério de Educação, 2018), obtained by teachers Patrícia Vieira Barbosa Faria and Jaqueline da Silva Nascimento, working at the municipal schools Raimunda Reis and Manoel de Paula Menezes Lima. 
Table 1. Comparison between ANA (INEP, 2017) and More Early Literacy Program (Ministério de Educação, 2018) results

\begin{tabular}{l|l|l|l|l}
\hline ANA, 2016 Levels In \%: & 1 & 2 & 3 & 4 \\
\hline Sergipe State & & & & \\
\hline More Early Literacy Program, 2018 & & & & \\
\hline Schools: Raimunda Reis & $\mathbf{8 . 7}$ & 56.5 & $\mathbf{3 4 . 8}$ & \\
\hline Manoel de Paula Menezes Lima & $\mathbf{9 . 1}$ & 59.1 & $\mathbf{3 1 . 8}$ & \\
\hline
\end{tabular}

The first column shows the percentages of students who barely identify one word or the other, while the last column shows the percentages of students who have a desirable reading performance. See how in the two Lagarto schools, where the SSA was applied in the years 2017 and 2018, level 1, dropped to less than 10\%, while at the highest level it reached the percentages of 34.8 and 31.8 .

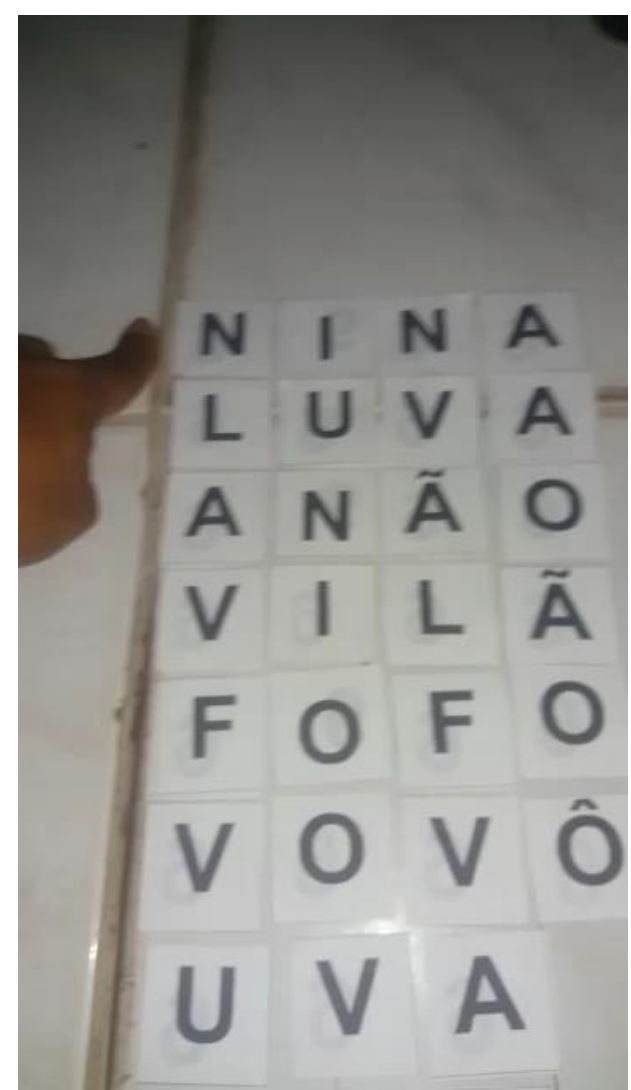

Figure 3. Child reading aloud words he has built with tokens 


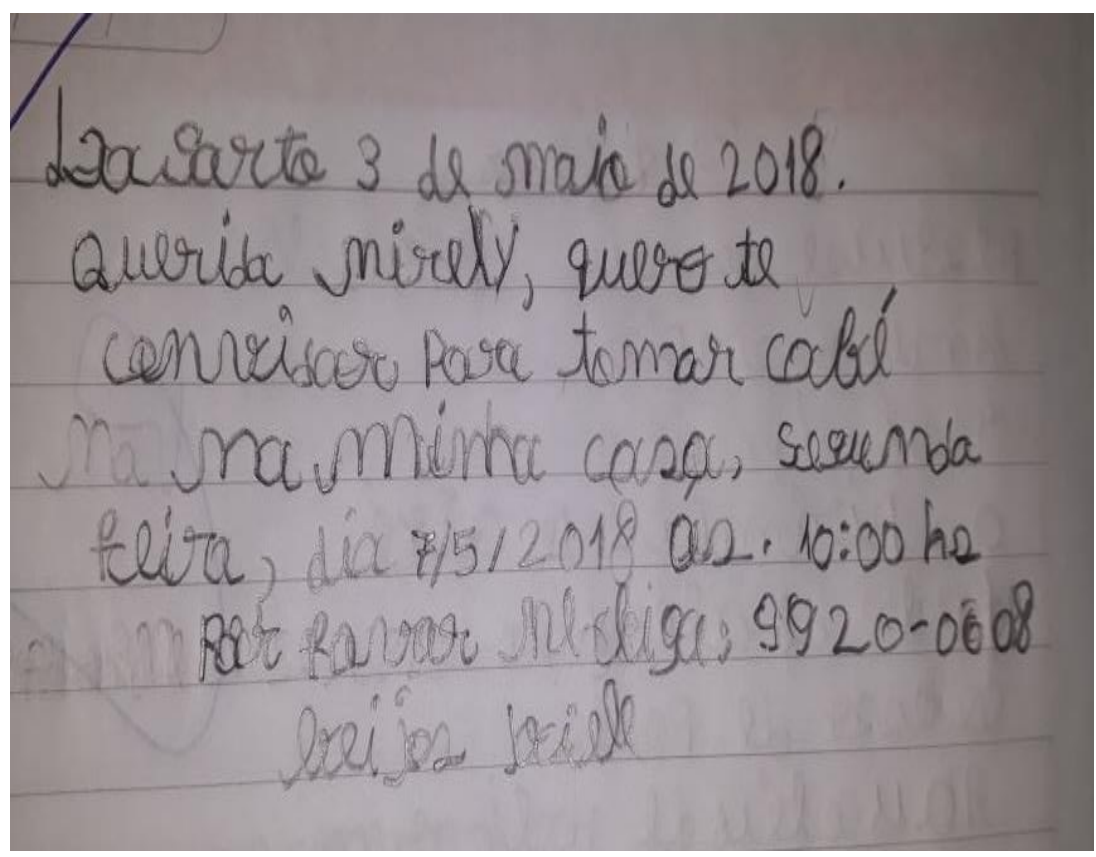

Figure 4. A cursive letter invitation written by a seven year old child from Lagarto

\section{Concluding Remarks}

I discussed the lack of linguistic and psycholinguistic fundamentals compromising the teaching-learning models of early literacy, as well as the ignorance of reading neuroscience most recent contributions, arguing with linguistic and neuroscience theories about perceptual invariant units, like phonemes and graphemes. I also explained the difference between phoneme and sound and between grapheme and letter as well as the existence of hierarchical linguistic levels.

Consequently, there was an introduction, in alphabetical writing systems, of two more levels, the one respecting the invariant features making up letters and the other respecting letters themselves, since the last ones perform graphemes, which motivated my original description of the Latin script letter invariant features. All those fundamentals pave the Scliar Early Literacy System (SSA), conceived to achieve full excellence literacy in Brazil. The exit obtained where it was applied, namely on the Brazilian Northeastern States, that showed the lowest scores in the 2016 National Literacy Assessment, ANA (INEP, 2017) empirically demonstrates the SSA contribution. The experiment ran at Lagarto, Sergipe State, reinforces it.

Lagarto Municipal Education Secretariat expanded its adhesion to SSA, reaching an average of 490 children from the $1^{\text {st }}(18$ classes $)$ and $2^{\text {nd }}$ ( 3 classes) grades of Elementary School, taking into account reading and writing, respectively. The Secretariat guaranteed the continuous training of 18 teachers who attend the $1^{\text {st }}$ year and the 5 who attend the $2^{\text {nd }}$ year for applying the SSA. In 2019, given the proposal success, more than 1000 children benefited from the project.

\section{References}

Carter, H. V., \& Gray, H. (1918). Gray's Anatomy, Plate 727. Anatomy of the Human Body, Public Domain. Available at: $<$ https://pt.wikipedia.org/wiki/Ficheiro:Gray727-Brodman.png > . Accessed on 19 Jan. 2020.

CTL. The Center of Teaching and Learning. (PDF) Alphabetic Principle. In: Big Ideas in Beginning Reading. Oregon: University of Oregon. Available at $<$ http://reading.uoregon. edu/>. Accessed on: July 23, 2020.

De Courtenay, J. N. B. (1972). A Baudouin de Courtenay anthology: The beginnings of structural linguistics. Bloomington, IN: Indiana University Press.

Dehaene, S. (2009). Reading in the brain - the science and evolution of a human invention. New York: Viking.

Grainger, J., Rey, A., \& Dufau, S. (2008). Letter Perception: from Pixels to Pandemonium. Trends in Cognitive Sciences, 12(10), 381-387. https://doi.org/10.1016/j.tics.2008.06.006

Hjelmslev, L. (1953), Prolegomena in a Theory of Language-Memoir 7. Baltimore: Indiana Publications in Anthropology and Linguistics.

IES, Institute of Education Center. (2006). The Health Literacy of America's Adults Results From the 2003 National 
Assessment of Adult Literacy. New Jersey: National Center for Education Statistics, September.

INEP. Instituto Nacional de Estudos e Pesquisas Educacionais Anísio Teixeira. Ministério de Educação. (2017). Sistema de avaliação da educação básica - Avaliação Nacional de Alfabetização. Available at $<$ http://portal.mec.gov.br/index.php?Option=comdocman\&view=download\&alias=75181-resultadosana-2016pdf\& category_slug=outubro-2017-pdf\&Item id=30192>. Accessed on Oct. 26, 2017.

Jakobson, R. (1971). Selected Writings: Word and Language. Berlin: Walter de Gruyter, v. 2. https://doi.org/10.1515/9783110873269

Kruszewsky, M. (1995). Writings in general linguistics. Amsterdam: John Benjamins Publishing. https://doi.org/10.1075/acil.11

McConkie, G. W., \& Rayner, K. (1975). The Span of the Effective Stimulus during a Fixation in Reading. Perception and Psychophysics, 17, 578-586. https://doi.org/10.3758/BF03203972

Michailowski, P. (1996). Mesopotamian cuneiform. In P. T. Daniels \& W. Bright (Eds.), The world's writing systems (pp. 33-72). New York/Oxford: Oxford Univ. Press.

Ministério de Educação. (2018). Resultados da Avaliação Diagnóstica. Portal do Programa Mais Avaliação. Available at $<$ http://portal.mec.gov.br/component/tags/tag/46201>. Accessed on Nov. 28, 2018.

Petersen, S. E., Fox, P. T., Posner, M. I., Mintun, M., \& Raichle, M. E. (1988). Positron Emission Tomographic Studies of the Cortical Anatomy of Single-word Processing. Nature, 331(6157), 585-589. https://doi.org/10.1038/331585a0

Ritner, R. K. (1996). In P. T. Daniels \& W. Bright (Eds.), The world's writing systems (pp. 73-84). New York/Oxford: Oxford Univ. Press.

Saussure, F. De. (1972). Cours de Linguistique Générale. Éd. Critique preparée par Tullio de Mauro. Paris: Payot.

Scliar-Cabral, L. (2003). Princípios do Sistema Alfabético do Português do Brasil. São Paulo: Editora Contexto.

Scliar-Cabral, L. (2009). Sagração do Alfabeto. São Paulo: Scortecci.

Scliar-Cabral, L. (2013). Sistema Scliar de alfabetização -Fundamentos. Florianópolis: Editora Lili.

Scliar-Cabral, L. (2014). Aventuras de Vivi. Florianópolis: Editora Lili.

Scliar-Cabral, L. (2018). Sistema Scliar de alfabetização. Roteiros para o professor. Florianópolis: Editora Lili.

Scliar-Cabral, L. (2019). Políticas Públicas de Alfabetização. Ilha do Desterro, 72(3), 271-290. https://doi.org/10.5007/2175-8026.2019v72n3p271

Scliar-Cabral, L. (2020a). Sistema Scliar de alfabetização. Caderno de Atividades: Módulo 1, Leitura. Florianópolis: Editora Lili.

Scliar-Cabral, L. (2020b). Sistema Scliar de alfabetização - Fundamentos da escrita. Florianópolis: Editora Lili.

Scliar-Cabral, L. (2020c). Sistema Scliar de alfabetização. Roteiros para o professor - Módulo 2, Escrita. Florianópolis: Editora Lili.

Scliar-Cabral, L. (2020d). Aventuras de Vivi no mundo da escrita. Florianópolis: Editora Lili.

Scliar-Cabral, L. (2020e). Sistema Scliar de alfabetização. Caderno de Atividades: Módulo 2, Escrita. Florianópolis: Editora Lili.

Spratting, M. W. (2005). Learning Viewpoint Invariant Perceptual Representations from Cluttered Images. IEEE Transactions on Pattern Analysis and Machine Inteligence, 27(5), 753-761. https://doi.org/10.1109/TPAMI.2005.105

Trubetskoy, N. S. (1970). Principes de Phonologie. Trad. J. Cantineau. Paris: C. Klincksiech.

\section{Copyrights}

Copyright for this article is retained by the author(s), with first publication rights granted to the journal.

This is an open-access article distributed under the terms and conditions of the Creative Commons Attribution license (http://creativecommons.org/licenses/by/4.0/). 